\title{
Promote upgrade of the enterprise culture and development strategic height of our country enterprise
}

\author{
Yao Li \\ Chutian college business school huazhong agricultural university Hubei wuhan 430205
}

Keywords: Enterprise culture; Enterprise development strategy; Learning organization; Ecological culture; Cross-cultural management

\begin{abstract}
Our country is facing a new round of important development period of strategic opportunities, and need to pay more attentions to study how to rely on cultural strength to drive productivity in market competition and to improve the overall strength and competitiveness of enterprise; This paper argues that China's enterprises still present deficiencies such as "shallow stratification", "appearance", "solification" and" formalization" and "decentralization", etc. The article suppose that, it is necessary to recognize the rich connotation of enterprise culture to advance enterprise culture to upgrade; And that enterprises must attach importance to the innovation of enterprise culture, cultural power as strong point and the focus of enterprise strategy, and rely on excellent enterprise culture to increase the height of enterprise development strategy.
\end{abstract}

\section{It is necessary to recognize the rich connotation of enterprise culture to advance enterprise culture to upgrade}

The concept of enterprise culture is proposed first in the "Business week" in 1980. Later, it soon becomes the focus of enterprise management research. "Business week" in America thinks: enterprise culture (i.e., a definition of the enterprise culture) mainly refers to the values, company application values "which are for the company's activities, opinions, and action to set an example through the practice of the manager, to be gradually instilled into the workers' minds and past to a successor." After that, classical expressions from many scholars for enterprise culture reveal deep and profound connotation of the enterprise culture from different angles. The representative views are:

First, enterprise culture is a values and behavior norms system which is commonly accepted and approved by all members of the organization.

T.E.D eal and A.A.K ennedy, the author of "Enterprise culture" monograph first published in 1982 in the United States, said: "the value standard is the foundation of any culture. As philosophy essence for a company on the road to success, it provides the concept of common direction for individual employees and their principles of daily life, and puts forward theoretically the essence of constituting corporate culture. These elements are: (1) enterprise environment, is the most important factor in shaping enterprise culture; (2) values, is the core to form enterprise culture; (3) hero image, is to make values personalized, specific model for employees to learn ; (4) ceremonies and rituals, is the way for the enterprise to deal with daily routine affairs systematically, designedly and orderly; (5) cultural network, is basic communication of the enterprise to pass values and sense of hero." The authors also believe that the company management center is a person, and managers should, through cultural subtle hint and informal planning, make them satisfied with their own things, and is willing to work hard and make a difference. Japanese scholars Wikipetia and Ikujiro Nonaka in their book " management comparison between the Japanese and American enterprise "(1983) also said:" the so-called enterprise culture, is for organization members to organize values with common understanding and common action, or to make the organization's values and norms system become justified cognizing system."

Secondly, enterprise culture is highly blending product of management and its social culture.

American scholar J.C. Aegllen, in the 50s in his treatise of "Japanese enterprises and their social organizations", focus on Japan social organizations and enterprises internal system research, 
think the Meiji restoration of have not fundamentally changed Japan's traditional social structure, and Japan's industrialization only brought the European and American advanced production technology into the traditional social structure and reconcile them, therefore producing a series of Japanese business management characteristics such as the lifetime employment. Agger belem also think Japan management experience has special significance, and he advocated "theory of difference", didn't agree with the "theory of convergence, convergence theory thinks that in the countries except the European and American countries, along with the development of industrialization, social structure will change, eventually tend to Europe and the United States social type. Japan's business will also lose features, finally to tend to European and American management system.) In his 1973 book "management and worker — countermeasures of Japan”, he stressed:" any social management organization wants to play a role effectively, it must be consistent with value standard and interpersonal relationship in this society, and industrialization is a great success in Japan, which is because of highly blending result of Japan's management organization and its social culture". Happen to that some of the most successful businesses in the United States also exist corporate culture which is similar to Japanese company culture and more contributed to the rise of American company culture.

Thirdly, enterprise culture, main body of culture, is closely associated with organizational strategy, and profoundly affects the success of the strategic thinking and strategic implementation.

In 1985, Davis, in his book "on corporate culture" when it come to attach importance to enterprise culture, thought economic environmental catastrophe and the increasingly competitive pressure made the enterprise develop a strategy to act quickly, and the company culture is the only catalyst to implement strategy. The management must explore a certain philosophical foundation, and should have a guiding ideology. Therefore, American business and management scholars, think highly of the role of corporate culture in enterprise management. Many enterprises emphasize corporate culture construction, aiming at the enterprise values become enterprise members' common values, through shared values to make internal control to let enterprise members to monitor and adjust their daily behavior consciously with the shared values as criterion, to enhance the enterprise's cohesion and centripetal force and power, working together to achieve the strategic goals of the enterprise. Therefore, the importance of enterprise culture on enterprise strategic management are known in many companies, for example, many consulting companies in the United States, such as management analysis center, Fu lang, the Boston consulting group, which specializes in the problems of the organizational design and strategy, are shifted to the customer analysis one after another, analyzing how to make the enterprise culture and corporate strategy coordinate. Before the 1970 s, American management scholars also just noticed the "real" aspects suh as management organization, management system, did not notice the function of enterprise values and action way on the management. The United States, because of the recession in the early 80s, amazed the vitality of Japanese companies so as to make in-depth study of Japanese business management, and they believed that Japan's corporate culture can work more than management organization system and management theory.

All in all, most of scholars agree that "culture" is a kind of invisible, soft factors associated with human. Corporate culture has the following characteristics. First of all, the enterprise culture refers to the common value system, it exists in groups rather than individuals, is shared by the members of organization, can play a dominated role for individual thinking and behaviors. Secondly, culture is a kind of consciousness, is a kind of thinking mode, and associate with members about how organizations. And this kind of perception will make what people think and do produce the invisible constraints and norms. Again, culture is invisible, but in a great extent determines the perspective and reaction of the world around you, thus can not be ignored. Many companies are now devoting themselves to enterprise culture construction, and this is the reason.

\section{The main problems and shortage of enterprise culture construction}

In the long-term social practice, when strengthen enterprise culture construction, the enterprise has made some beneficial exploration and achieved some results. However, in the face of the new 
situation with great development and prosperity of socialist culture, not all companies can be consciously aware of the important role of corporate culture in the development of contemporary enterprises; And, for those enterprise which have realized the important role of the enterprise culture in modern enterprise development, not all of them can build a enterprise culture which corresponds to enterprise reality so that they can really promote the enterprise development. As the old industrial base Hubei, the state-owned enterprise construction development history is longer. Many large state-owned companies from the early 80s began to pay attention to cultural construction, and formed their own spirit of enterprise culture. But as the market economic system gradually established and perfected, the original enterprise culture spirit and the establishment and perfection of the modern enterprise system have many aspects not in coordination, and there are still some gaps with the modern enterprise management, economic and social development and the needs of the masses of the people. Most of enterprises are in the stage that they only recognize the important role of enterprise culture but fail to build a enterprise culture which corresponds to enterprise reality so that they can really promote the enterprise development.

Enterprise culture construction and practice also many problems including different thought and behaviors in corporate culture, content convergence, loss of the enterprise ethics culture, not strong corporate social responsibility, lack of cultural innovation mechanism. They main perform the following features:

1 The understanding and attention of corporate culture is not enough. The vast majority of the enterprise did not recognize the essence of corporate culture, just understand the enterprise culture from the slogan. According to the survey, in Wenzhou, gathering places of small and medium-sized enterprises in our country, there are $60 \%$ of business leaders not fully realize the necessity of enterprise culture, some enterprise has a specialized agency, which is also useless. Business operators do not step in, not pay attention to, not enroll the corporate culture strategy into the overall strategy for the enterprise development plan, the provision power of enterprise management principle of involving the content such as enterprise mission, aims and objectives is not enough.

2 Enterprise culture lacks of core values and business philosophy. Core values and business philosophy are the soul of enterprises, determine the enterprise development strategy and the development direction in the future, and have a significant impact on the whole enterprise operation and management activities.According to the survey, most of the state-owned enterprises in hubei province have not complete definition of the enterprise values, the emergence of this phenomenon may be because some business leaders don't know what is the enterprise values, or only pay attention to economic benefit and take less care of the enterprise's social responsibility for the society and employees; There are so many enterprises which confuse values with spirit of the enterprise. Because there is no or not suitable for the enterprise values, it also make the enterprise lose the choice standard of value, the enterprise behavior is easy for casual to business leaders subjective will, also easy to cause the lack of social responsibility. As some enterprises one-sided understand enterprise culture construction, think the enterprise culture is the pursuit of lower costs and seeks to improve efficiency, and perform management behavior lack of honesty business ethics including cutting corners, and sale of counterfeit goods, quality and price fraud, resulted in a shrinking market. Heavy duty and light power to employees inhibit the enthusiasm and creativity of employees, leading to brain drain. The enterprises lack of the core values, when providing products and services, not well deal with the relationship between the immediate interests and long-term interests, easily change their management style with the surrounding market environment change, and they also have not the continuity and relative stability of enterprise system, killing some promising projects and promising products, cannot thrive.

3 The enterprise ethics culture is lost, and social responsibility is not strong. The enterprise ethics culture is the foundation of enterprise culture, is the power source of the enterprise culture. The enterprise ethics culture is based on a certain philosophy theory as theoretical support, according to the established social standard of conduct and ethics for the enterprise pursues, is bearing of the enterprise culture, and has a key role for the effective and positive formation and 
function of enterprise culture, is also important guarantee for the efficiency of enterprise management and enterprise sustainable development. The enterprise ethics culture and the spirit of enterprise can be able to motivate employees to create corporate earnings permanently, become the soul of enterprise development and guide, is also the foundation for enterprises to fulfill social responsibility. The enterprise ethics culture and the spirit of enterprise as the core of the enterprise construction, occupy an important position. The essence of enterprise culture construction is to refine what is most important concept in the enterprise development.

4 The core status of human-oriented culture is not enough. The key to enterprise development is enterprise staff's enthusiasm and creativity, "people-oriented" is the core spirit of enterprise culture. According to the survey, many current Hubei enterprises did not deeply understand the important significance of "people" in the construction of corporate culture, and ignore the human existence and value, just regard people as tools and means of profit, didn't look satisfaction people's development and meeting the needs of the people as the purpose, not see that people are integrity of purpose and means. Some enterprises even proposed to adhere to people-oriented, but paid less attention to the person's psychology and spirit, ignored the human resources development, made the people-oriented stay on the slogan, causing the fact that the workers are free from the enterprise culture construction, attractive, motivating function of enterprise culture hasn't been really formed.

5 The enterprise culture innovation mechanism is lost. Lack of innovation mechanism of enterprise culture in Hubei province presents "shallow stratification", "appearance", "solification" and" formalization" and "decentralization" five shortages: one is to make enterprise culture "shallow stratification". Many enterprises have relatively shallow understanding of enterprise culture, just in order to shape the cultural image, even divorce from reality and sum up some not recognized business philosophy or enterprise spirit away from the actual; The second is to make enterprise culture "appearance". The enterprise culture is only as mere form to build enterprise exterior environment. Many companies lose mind in and take efforts on the enterprise appearance color, plants and trees and clothing, in the face of the enterprise culture core value shaping they put the cart before the horse.Third is to make enterprise culture "solid". They think the enterprise culture permanent things once set up, ignore innovation in time according to the environment, age, changes in the market, make inappropriate culture become barriers in the development of enterprises; Fourth is to make enterprise culture " formalization". Some enterprises in the form exist formalism, fashionable ideas, think the enterprise culture is singing and dancing, playing a ball game and enjoying entertainment, setting up the team and band, etc., lack of in-depth thinking with practice and clear comb to own enterprise problems, can't accurately grasp the enterprise culture construction principles and main point; Fifth is to make enterprise culture "decentralization". The whole power of corporate culture innovation is not formed, such as some enterprises only attach importance to culture construction of big companies, and ignore the branch culture, team culture, safety, quality and marketing professional culture these grassroots cultural construction and development. The innovation genes have not been implanted to the grass-roots staff, and whole power has not been formed, enduring corporate culture is less likely to grow out.

\section{Further upgrade enterprise culture, and promote the strategic height of our country enterprise development}

In the process of moving towards a new century, no matter east and west, culture has become more rich, more complex, more open, more influenced on each other, and the influence of culture on the development of social economy is also more important. The cultural background of economy development, not as it did in the past, it has to do with the relationship between people, information, technology and nature more closely than any time in the past. The development of enterprises will more depend on the person's knowledge, quality, moral, cultural attitude, innovative spirit and creative ability. So to speak, the 21st century is the age of the culture, and the role of culture in the social development is more and more big, the cultural and economic ties are more and more close. In order to adapt to the change of the economic development, there is a larger degree of innovation in the enterprise culture. 
The 17th national congress of the CPC put forward to enhance the important culture position in economic and social development, raised the development of the culture to the important strategic height. The 18th national congress of the CPC explicitly put forward development goals of new period which is " culture soft power will remarkably increase and the system of socialist core values will be deeply rooted in the hearts of the people, the culture industry will become a pillar industry of national economy, and the basis of socialist cultural power construction will be more solid." At present, our country is facing a new round of important development period of strategic opportunities, and need to pay more attentions to study how to rely on cultural strength to drive productivity in market competition and to improve the overall strength and competitiveness of enterprise; This paper argues that the enterprise culture is an important factor for the success of the strategy implementation, to a certain extent, enterprise culture plays an decisive role in strategy implementation. So we have to reach such a consensus, that is, development and expansion of enterprises, must attach importance to the innovation of enterprise culture, cultural power as strong point and the focus of enterprise strategy, relying on excellent enterprise culture, to enhance the height of the enterprise development strategy, and bring enterprise culture and innovation into the enterprise development strategic planning, which should be put into details of the enterprise management. How to promote the upgrade of enterprise culture in our country, this paper argues that in the current and future period the following aspects should be as the focus of the enterprise culture upgrade.

1. The corporate culture should pay more attention to the development of human resources, and give strong support for status of human capital in the enterprise on the concept of value.

At present, the world economy has gone into the era of knowledge economy, and knowledge economy is a new type of economic form based on the production, dissemination and use of knowledge. The corporate culture based on the information in the new economic era, whether it is the basic value idea, or a specific code of conduct, to a large extent, is different from the traditional corporate culture. Knowledge, as the unique factors of production, is the only significant resources. "Capitalists" who master and create knowledge has become the source of power in the development of enterprises. Due to the intelligentization of factors of production in the era of knowledge-driven economy, the value of people is immeasurable, is the most perfect resource in society, is the most dazzling pearl in the productivity. The development of human resources maximizing has been incorporated into all aspects of production and business operation, new distribution system that enterprises with business knowledge and human resources of demutualisation and employees share the profits distribution system has been generally promoted, people-oriented innovation has become the golden rule in the development of enterprises. This requires enterprise management turn to people-centered to motivate creativity. For this purpose, the enterprise culture should be culture emphasized diversity with the complex structure, which allows cross areas, encourages innovation, and promotes collective cooperation and team spirit. And enterprise culture is the effective ways to seek the dynamic balance between efficiency logic and emotional logic, "attach great importance to the people, respect and understand people" management thinking mode and the creation of a positive corporate culture is the most effective way to harmonize relations between the interests of the organization, to play group synergistic effect and to increase the enterprise cohesion.

2 Corporate culture should pay more attention to the cultivation of the learning environment and the construction of learning organization in the business enterprise.

Due to the rapid development of technology, economy, and a sharp growth of knowledge quality, rapid response of enterprise, the only way to improve resilience is to make the enterprise into a learning organization. Learning organization is team learning which is good at learning (contains the connotation of lifelong learning, full learning, the whole process learning and group learning), in order to realize the transformation from linear thinking to the system thinking and creative thinking, emphasizes the force of system thinking and knowledge integration, emphasizes to achieve a common vision with condensed and collective wisdom, constantly breakthroughs the limit of tissue growth, so that the organization havs the ability to continuously improve, keep sustainable 
development; On the other hand, the learning organization is not only to acquire knowledge and information, also attaches great importance to the fundamental change of mind, which will let every member live out the true meaning of life, thus greatly enhance the ability of organization innovation and creativity to create the future. So under the background of new economy, the real good organization is a organization which will be able to try to make all levels of staff devote themselves to learning and have the ability to keep on learning.

From the view of knowledge, the enterprise organization is an organization for integration of knowledge. In order to enhance the competitiveness of the enterprises under the condition of knowledge economy, the world's top 500 enterprises also pay much attention to improve the organization's overall ability to learn, in the world's top 100 enterprises, $40 \%$ of the enterprises regard "learning organization" as sample, thoroughly reborn renovation. Through these measures, they strengthen international competitiveness. All outstanding enterprises have selected a own pattern, and this kind of model is consistent with the company's strategic development and culture.

3. The corporate culture should be combined with ecological culture, and regard ecological civilization as another important aim of the enterprise.

Ecological culture is a new kind of culture idea in the new economic era, is also a new type of management theory, which, as well as corporate culture, belongs to a kind of development value with the goal of sustainable development. It makes people a fundamental shift in dealing with the issue of people and nature, people and the environment. The traditional industrial economy emphasizes matter and energy production, and most of the its industry are capital-intensive industries. The enterprises only consider to use of natural resources as much as possible to achieve maximum profits, not consider or rarely consider the environmental benefits, ecological benefits and social benefits. Therefore, global resources huge waste was brought, in the era of knowledge economy the center of gravity is the production and use of knowledge, we should pay attention to use existing resources scientifically, reasonably and efficiently, and develop rich resources not been used, therefore, the new economy is a new form of economic growth, the goal is protection of the ecological environment and human's long-term development, and its essence is ecological civilization. When the development of enterprise culture combines with the ecological culture, ecological civilization as an important content of enterprise culture construction, it will lead the development of the enterprise to coordinated development track with enterprise and environment, society and nature.

4. The enterprise culture should from the unit develop into the direction of pluralism, compatibility and coordination, making the enterprise culture become an "open" system.

Growing with the increase of the trend of world economic regionalization and integration day by day, economic exchanges between countries are increasingly close, international business has become effective operation and organization form chose by more and more companies.In the multinational enterprise, employees from different countries and different ethnic groups have different cultural background, there are different levels of cultural differences within the enterprise, and the enterprise culture contains the characteristics of multicultural. Legal culture and social culture and many cultures differences in different countries, not only make the enterprise market environment and market demand change, also make the organization management be faced with more complexity and uncertainty of decision-making, the conflict of the cultural values and collision of management system are inevitable. All the facts prompt companies easier to analyze and understand the problem from the multi-level and multi-angle, and management is more flexible and art; On the other hand, facing the international environment and human resources with cultural diversity, enterprises also take in the enterprise intelligence, knowledge, thinking and complement each other's advantages, which is more easy to develop new ideas, new ideas and new thoughts, and more advantageous to improve the organizational efficiency and competitiveness. Multinational companies pay more attention to cross-cultural management. Cross-cultural management leads the management focus to the understanding of the multicultural culture which enterprises have and the cultural differences, and overcomes the difficulties brought about by the pluralistic culture and 
cultural differences, use multicultural culture as resources and advantages of enterprises. By recognizing cultural differences (identify types of cultural differences, and put forward a solution to the cultural differences), to conduct cultural selection (select and absorb excellent compositions in foreign culture, and make fused enterprise culture with the advantage of "hybrid"), and realize cultural identity (let the members of different cultural backgrounds to understand, concern and identify each other, and set up the enterprise own standard, realize identity of culture).The allowance of the coexistence of different cultures has the vital significance in the possible coordination of enterprise culture

\section{The enterprise culture should be paid more attention to set up enterprise good} organization image.

In knowledge economy era, the focus of enterprise management will realize transformation from tangible "matter" to intangible "knowledge", the competition between enterprises is no longer the competition with traditional sense which just stays in terms of some individual or a single level, but from individual or local products competition, price competition, technological competition, competition for resources transfers to the competition of enterprise image and the overall strength. In the competition for the strong companies, who can set up good enterprise image identified by the vast number of consumers, who can be in an impregnable position. And fuzzy and poor corporate image can make the enterprise at a competitive disadvantage, even lead to a death. Good organization image has become a huge intangible asset. Enterprise image is overall impression, opinion and evaluation from the public to the organization's, is public opinion about the overall state of the organization, and reflects the public's perception to organization, public feelings and intentions. Corporate image has many effects on the enterprise: it can improve enterprise's popularity, attract talent, motivate staff morale, and form a good working atmosphere; Outside it can enhance goodwill and confidence of investors, expand awareness of enterprise brand and brand, make the enterprise have high popularity and good reputation, get the welcome and goodwill of consumer market, consolidate the market position of the enterprise, and build a harmonious and loose development environment for the enterprise. Therefore, creating a organization image with deep cultural inside information that society can accept and making the organization image have more strong radiation force, have become one of the common goals modern enterprise pursues generally.

\section{References}

[1] Wang weigang, 2012, Status and improvement of state-owned enterprise culture construction. Urban construction theory research (6)

[2] Gong xiangchen, 2012, The theory of state-owned enterprise culture present situation and improving countermeasures. Shandong social science, (6)

[3] Xiong Xiangping, 2007, The old state-owned enterprises cultural reconstruction and the functions of the propaganda department, Journal of Huang gang normal university, (4)

[4] Dai haiyan, 2006, The implementation main body of enterprise culture and strategy_- the perspective of game theory. The mall modernization, (29)

[5] Chen jing, 2010, Chinese high-tech park enterprise innovation culture construction research. Journal of Beijing university of aeronautics and astronautics (social science edition), (2) 